Jurnal Manajemen Indonesia Vol. 21(2), pp. 171-182, 2021)

Online ISSN : 2502-3713 | Print ISSN : 1411-7835

This Journal is available in Telkom University online Journals

Jurnal Manajemen Indonesia

Telkom

Journal homepage: journals.telkomuniversity.ac.id/ijm

\title{
Digital Innovation and Capability to Create Competitiveness Model of Cooperatives in Bandung, Indonesia
}

\author{
Ratri Wahyuningtyas $^{1}$, Ganjar M Disastra ${ }^{2}$, Risris Rismayani ${ }^{3}$ \\ ${ }^{1,3}$ School of Economics and Business, Telkom University, acronyms acceptable, Bandung, Indonesia \\ ${ }^{2}$ School of Applied Science, Telkom University, acronyms acceptable, Bandung, Indonesia
}

\begin{abstract}
Digital innovation refers to innovations that take advantage of digital technology to obtain new results from digitalization. Currently the digital innovation process has been implemented in a competitive and cooperative setting. Cooperatives as social organizations are required to be able to follow environmental regulations by implementing digital innovation to accelerate national economic growth, reduce poverty levels, and support equitable distribution of people's income. The inability of cooperatives to adapt to meet needs and balance the era of the industrial revolution 4.0 will result in a downturn in cooperative management, such as what happened in 2017 where almost $40 \%$ of cooperatives in West Java were inactive. In digital innovation, digital capability are also needed to connect digital technology with professional digital talent. The purpose of this study is to identify and formulate a competitiveness model through digital innovation and capabilities with government support for cooperatives in Bandung. Primary data technique consists of distributing questionnaires, interviews and secondary data through literature studies.
\end{abstract}

Keywords-Digital innovation; capabilities; competitiveness; cooperatives

\begin{abstract}
Abstrak
Inovasi digital merujuk pada inovasi yang memanfaatkan teknologi digital untuk memperoleh penciptaan baru dari digitalisasi. Saat ini proses inovasi digital telah diimplementasikan dalam pengaturan yang bersifat kompetitif dan kooperatif. Koperasi sebagai organisasi sosial dituntut untuk dapat beradaptasi dengan tuntutan lingkungan dengan menerapkan inovasi digital untuk mempercepat pertumbuhan ekonomi nasional, menurunkan tingkat kemiskinan, dan mendukung pemerataan pendapatan masyarakat. Ketidakmampuan Koperasi dalam beradaptasi untuk memenuhi kebutuhan dan mengimbangi era revolusi industri 4.0 akan mengakibatkan keterpurukan dalam pengelolaan koperasi seperti yang terjadi pada tahun 2017 dimana terdapat hampir 40\% koperasi di Jawa Barat berstatus tidak aktif. Dalam inovasi digital, kemampuan digital juga diperlukan untuk menghubungkan teknologi digital dengan talenta digital profesional. Tujuan penelitian ini adalah untuk mengidentifikasi dan memformulasikan model daya saing melalui inovasi dan kapabilitas digital dengan adanya dukungan pemerintah untuk koperasi di Kota bandung. Teknik pengumpulan data primer terdiri dari penyebaran kuesioner, wawancara dan pengumpulan data sekunder melalui studi literatur.
\end{abstract}

Kata kunci — Inovasi digital; kapabilitas; daya saing; koperasi

\section{INTRODUCTION}

According to the Indonesian Cooperative Ministry Regulation number 09 year 2018, cooperatives are business entities with members or cooperative legal entities based on activities by carrying out activities based on cooperative principles and as a family economic movement of the people. In addition, cooperatives have a role in 
developing the economic potential and capacity of members and communities to increase socio-economic welfare; strengthening the people's economy as the basis for the strength of the national economy; developing the national economy as a joint effort based on the principles of kinship and economic democracy. There are 1015 cooperatives in Bandung with 163 cooperatives that are not active as seen in Figure 1.

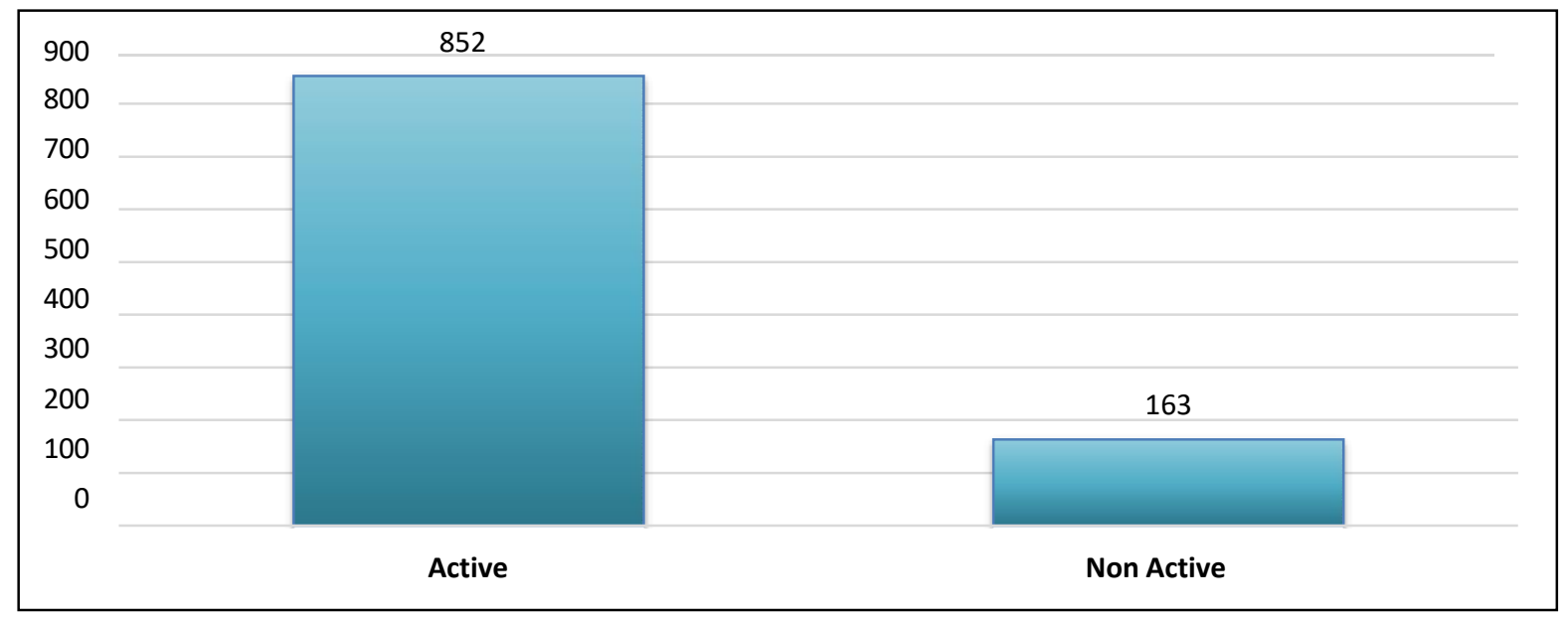

Figure 1. Cooperatives in Bandung

The presentation at the Cooperatives and Small Business Office Coordination Meeting in 2018 stated that one of the things that caused this condition to occur was the low level of human resource skills and the lack of innovation as a form of readiness to face challenges in the digitalization era. According to the Secretary of the Ministry of Cooperatives and SMEs, Prof. Rully Indrawan, West Java Cooperatives must change the way of doing business by taking advantage of developments in information technology (m.tribunnews.com, 2019). Every employee of a cooperative is required to have creativity and innovation to take advantage of digital technology in its management so as to accelerate the process of adaptation and transformation in the face of environmental changes. In 2018, from 265.4 million population in Indonesia, 130 million were actively using social media and 132.7 million using the internet, with $67 \%$ using it for information searches. Therefor cooperatives need to seize market opportunities both nationally and internationally through the ownership of employees who are reliable in utilizing digital technology. The purpose of this research to identify and formulate a competitiveness model through digital innovation and capabilities with government support for cooperatives in Bandung. The urgency of this research is to answer the challenge that cooperatives must be able to improve performance by creating global competitiveness through digital innovation and human resource capabilities. The originality of this research is that there are still very few researches that discuss digitalization as competitiveness in cooperatives, especially in West Java. There has never been a research that focuses on the relationship between digital innovation and capability to create cooperative's competitiveness with the support from the government.

\section{LITERATURE REVIEW}

\section{A. Government Support}

The government is one of the stakeholders in the micro, small and medium enterprises (MSME) environment. One form of participation is by providing general support and infrastructure for industry or MSME innovation activities. Government support can be delivered in the form of industrial scientific and technical support, advisory support, financial support, information support, managerial and professional learning and development support, and export support (Kolisnichenko, 2017). The government can play a role in corporate innovation through financial and policy support. Government funding support will be allocated for the company's research and development needs, and have a statistically significant positive effect on the company's innovation output or performance (Kim \& Lee, 2011; Wei \& Liu, 2015). Although it is not proven statistically significant, research and development funding support from the government also has a positive effect on the level of company innovation (Kim \& Lee, 2011). Alternative government support in the form of regional innovation policies also has a positive relationship with the company's innovation performance (Wei \& Liu, 2015). In the context of financial support 
from the government to MSMEs, research conducted by Dobes et al. (2017), indicating that financial support has an effect on business competitiveness. Anwar and Li (2020) confirm the relationship between financial and nonfinancial support from the government which has a positive and significant impact on financial performance and competitiveness of MSMEs.

\section{B. Digital Innovation}

Digital innovation is defined as the implementation of new ideas in the form of the creation of market offerings, business processes or models resulting from the use of digital technology (Nambisan et al., 2017; Garud et al., 2013). Research by Henfridsson et al. (2014) showed how the unique nature of digital technology enables a new type of innovation process that differs from the analog innovation of the industrial age. Digital innovation has three key characteristics, namely convergence, generativity and distributed nature (Hoffmann, 2018). The use of digital technology is emphasized in this definition, regardless of the various forms of products and / or services that can be produced from the innovation. Digital innovation can be explained by several dimensions, namely the quality of digital solutions, digital solution features, application / application of digital solutions, and differences in digital product platforms from competitors (Khin \& Ho, 2019; Paladino, 2007). The company's innovation activities significantly influence competitiveness through the creation of abilities or skills that competitors cannot imitate (Hana, 2013). Companies can gain their competitiveness by having the ability to produce products and / or services at lower prices with better quality than. In the context of MSMEs, digital technology which is the focal point for digital innovation contributes to the growth of business performance. This contribution was achieved by reducing communication and transaction costs, as well as improving relationships with consumers and suppliers (Asunka, 2016).

\section{Digital Capability}

In digital innovation, digital capability are needed to connect digital technology with professional digital talent (Khin \& Ho, 2019). Digital Capability covers the scope of managerial side and organizational side. Dynamic managerial capabilities include the ability of managers to build, integrate, and manage organizational competencies and resources (Adner \& Helfat, 2003). Dynamic managerial capability consists of three main dimensions, namely managerial cognition, managerial social capital, and managerial human capital (Helfat \& Martin, 2015; Li et al., 2018). Meanwhile, organizational capability is the organizational capacity to carry out certain activities reliably to achieve a minimum level of satisfaction (Helfat \& Winter, 2011). In supporting the success of the digital transformation process, especially in the scope of small and medium enterprises (SMEs), it is determined by the ownership of three aspects, namely understanding on digital business, platform utilization capabilities, and business development capabilities (Li et al., 2018). Digital capabilities, as represented by DMC, have a relationship to innovation. In empirical research conducted by Khan et al. (2020), found that there was a significant positive relationship between DMCs and the innovation performance of MSMEs. In addition, DMCs are also a mediator in the relationship between dominant logic (information filtering and learning routines) on innovation performance. So, it recommends that MSMEs need to develop their managerial capabilities to improve the company's innovation performance.

\section{Competitiveness}

The concept of competitiveness is a cross-disciplinary concept, including comparative advantage, price competitiveness, and strategic perspectives, which can be applied at various levels, starting from the company, industry, or macroeconomic level (Nelson, 1992; Waheeduzzaman \& Ryans, 1996). The concept of competitiveness in MSMEs has become a hot topic researched by recent research. Although it should be included in the company level, the concept of competitiveness in MSMEs will not be entirely the same as companies at the corporate level. Specifically for MSMEs, competitiveness is explained by three factors, namely profitability, efficiency, and growth (Wisenthige \& Guoping, 2016). The creation and maintenance of firm competitiveness is influenced by various factors. Government support in the form of financial incentives has a positive effect on company competitiveness (Anwar \& Li, 2020; Dobes et al., 2017). In the context of digital transformation, digital capabilities also have a significant positive effect on financial performance and competitiveness, when moderated by corporate digital innovation. (Hartono \& Halim, 2020; Khin \& Ho, 2019). In addition to moderating the relationship between digital capabilities, the discourse on the positive relationship between innovation and company competitiveness is also supported by research conducted by (Asunka, 2016; Hana, 2013). Based on the description of the relationship between variables, the conceptual framework as a model for this research can be seen in Figure 2. 


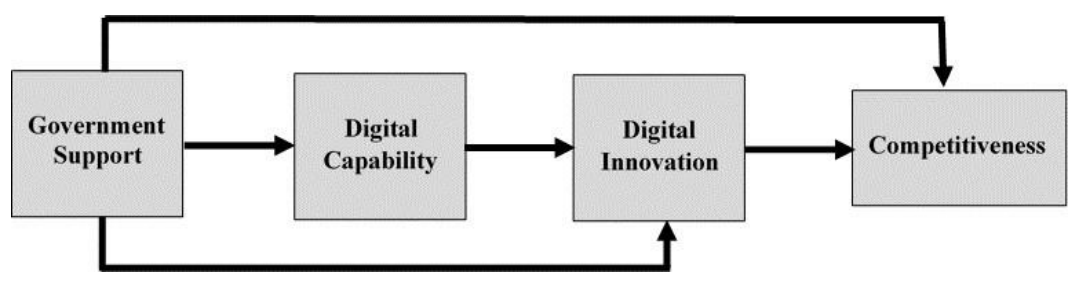

Figure 2. Conceptual Framework

\section{E. Hypotheses}

H1: Government support (DUKP) affects digital capability (KD)

H2: Government support (DUKP) affects digital innovation (ID)

H3: Government support (DUKP) affects competitiveness (DS)

H4: digital capabilities (KD) affects digital innovation (ID)

H5: Digital innovation (ID) affects competitiveness (DS)

\section{RESEARCH METHODS}

This type of research is an explanatory research type. This study aims to explain the influence between variables through hypothesis testing and at the same time to explain several variables. In accordance with the research objectives, namely to analyze, test and confirm the effect of Government Support, Digital Capability, and Digital Innovation on the Competitiveness of Cooperatives in Bandung. The population in this study were cooperatives in the city of Bandung which were actively operating until 2020. By using purposive sampling technique, the number of cooperatives in the city of Bandung used in this study were 82 cooperatives. In this study, there are 4 variables, namely government support, digital capabilities, digital innovation and competitiveness. The statements in the survey related to Government Support based on Kolisnichenko (2017) consisted of 31 statements, Digital Capability based on Li et al. (2017) consists of 14 statements, Digital Innovation based on Paladino (2007) consists of 6 statements and Competitiveness based on Wisenthige and Guoping (2016) consists of 6 statements. To achieve the research objectives and hypothesis testing, the data obtained will be processed according to the needs of the analysis. In this study, the data that has been obtained will be tested using the SmartPLS program. This program is an alternative to structural equation modeling (Structural Equation Modeling), which is to test simultaneously the relationship between latent constructs in linear and non-linear relationships with many indicators in the form of reflexive, formative or Mimic modes (Ghozali \& Latan, 2014). The stages of analysis using PLS must go through at least five process stages where each stage will affect the next stage, namely Conceptualization of the model, Determining the Algorithm Analysis Method, Determining the Resampling Method, Drawing Path Diagram and Model Evaluation.

\section{RESULT AND DISCUSSION}

Characteristics of respondents consist of gender, age and company age. The number of male respondents was $58.54 \%$ and the number of female respondents was $41.46 \%$. Based on age, the number of respondents who were under 27 years old was $70.73 \%$, respondents aged between 27 to 32 years were $2.44 \%$, respondents aged between 33 to 38 years were $8.54 \%$, respondents aged between 39 to 44 years were $18.29 \%$, and there are no respondents who are over 45 years old. This data shows that all of the cooperative managers in the object of this study are of productive age and even the majority are under 27 years of age. Other characteristics show that $76.83 \%$ of cooperatives have been established for more than 12 years, $10.98 \%$ have been established for 9 to 11 years, $7.32 \%$ have been established for 6 to 8 years, $2.44 \%$ have been established for 2 to 5 years, and $2.44 \%$ have been around for less than 2 years. This data shows that the majority of respondents are managers of cooperatives that have been around for more than 12 years.

\section{A. Descriptive Analysis}

Descriptive analysis was carried out to provide a picture of the respondent's responses to the research variables, which included the variables of Digital Capability (KD), Digital Innovation (ID), Government Support (DUKP) 
and Competitiveness (DS). As explained in the research methods section, the responses of respondents to this qualitative questionnaire were converted quantitatively to produce an answer score per item and an accumulated total score for each variable. The first variable is Digital Capability which consists of 14 statements. Referring to the results of data processing, the highest answer score is in the statement item, namely regarding the ownership of digital knowledge. While the lowest answer score is found in the statement regarding the knowledge of the cooperative management to predict future business developments. The total score obtained is 4303 , or $74.97 \%$ of the total ideal score. According to respondents, the level of digital capabilities of cooperative managers is at a "high" level. The second variable is Digital Innovation which consists of 6 statements. The statement of the uniqueness of the digital application applied by the cooperative compared to competitors has the highest score and the statement of the novelty of digital products produced by the cooperative has the lowest score. The total score obtained is 1671 , or $67.93 \%$ of the total ideal score. The level of digital capabilities of cooperative managers is at the "Intermediate" level. The third variable is the Government Support variable which measures the respondent's perception of the support provided by the government for cooperatives which consists of 31 statements. The highest score is the statement that the government provides access to information and international networks that have the opportunity to become a partner, while the lowest score is on the statement of funding for cooperative business from the government. The total score obtained is 8788 , or $69.14 \%$ of the total ideal score. From these results it can be concluded that the support provided by the government to cooperative managers is at the "Middle" level. The next variable is Cooperative Competitiveness which consists of 6 statements. The statement regarding the level of risk for the cooperative to experience financial difficulties had the highest score and the statement regarding the cooperative's ability to increase sales each year had the lowest score. The total score obtained is 1787 , or $72.64 \%$ of the total ideal score. According to the respondents, the competitiveness of the cooperatives they manage is at a "high" level. Figure 3 shows a summary of the average score for each variable as described previously.

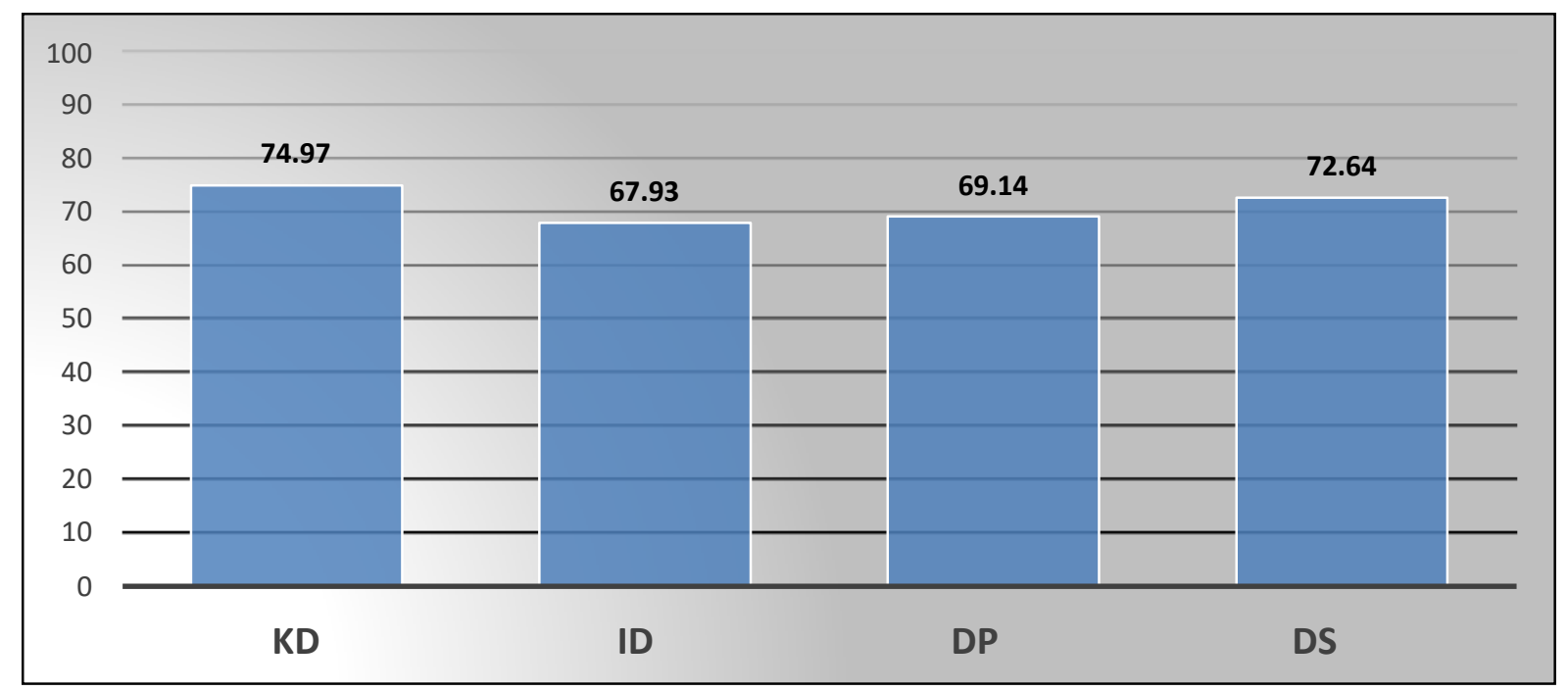

Figure 3. Score of Variable

\section{B. Hypotheses Testing}

This study tested the hypothesis by applying the Partial Least Square (PLS) approach assisted by the SmartPLS software developed by Ringle et al. (2005). One of the advantages of PLS is that it allows the researcher to simultaneously examine a series of interrelated dependency relationships between the measured variable and the latent constructs and between multiple latent constructs. In addition, the PLS method demands much less requirements on sample size and distribution compared to covariance analysis, does not require normally distributed input data, but provides consistent and reliable results and can be applied to complex structural equation models with a large number of constructs (Urbach \& Ahlemann, 2010). This study uses a two-step approach (two steps appoach) to analyze two aspects, namely: measurement models and structural models, as suggested by Anderson and Gerbing (1988). The purpose of this approach is to assess the suitability and validity of the measurement constructs before assessing the structural model for path coefficients or relationships between variables. 


\section{a. Analysis of Measurement Model (Outer Model)}

Table 1. Convergent Validity

\begin{tabular}{|c|c|c|c|c|}
\hline Variable & Item & Loading Factor & $\overline{A V E}$ & $\mathbf{C R}$ \\
\hline \multirow[t]{13}{*}{ Digital Capability } & 1 & 0.888 & 0.975 & 0.977 \\
\hline & 2 & 0.891 & & \\
\hline & 3 & 0.907 & & \\
\hline & 4 & 0.935 & & \\
\hline & 5 & 0.719 & & \\
\hline & 7 & 0.920 & & \\
\hline & 8 & 0.906 & & \\
\hline & 9 & 0.901 & & \\
\hline & 10 & 0.869 & & \\
\hline & 11 & 0.786 & & \\
\hline & 12 & 0.868 & & \\
\hline & 13 & 0.884 & & \\
\hline & 14 & 0.902 & & \\
\hline \multirow[t]{27}{*}{ Government Support } & 1 & 0.885 & 0.990 & 0.990 \\
\hline & 2 & 0.887 & & \\
\hline & 4 & 0.901 & & \\
\hline & 5 & 0.894 & & \\
\hline & 6 & 0.766 & & \\
\hline & 7 & 0.875 & & \\
\hline & 8 & 0.915 & & \\
\hline & 9 & 0.897 & & \\
\hline & 10 & 0.842 & & \\
\hline & 11 & 0.855 & & \\
\hline & 12 & 0.863 & & \\
\hline & 13 & 0.908 & & \\
\hline & 14 & 0.902 & & \\
\hline & 15 & 0.915 & & \\
\hline & 16 & 0.922 & & \\
\hline & 17 & 0.913 & & \\
\hline & 18 & 0.925 & & \\
\hline & 19 & 0.893 & & \\
\hline & 20 & 0.862 & & \\
\hline & 21 & 0.897 & & \\
\hline & 22 & 0.906 & & \\
\hline & 23 & 0.883 & & \\
\hline & 27 & 0.920 & & \\
\hline & 28 & 0.896 & & \\
\hline & 29 & 0.894 & & \\
\hline & 30 & 0.889 & & \\
\hline & 31 & 0.888 & & \\
\hline \multirow[t]{6}{*}{ Digital Innovation } & 1 & 0.947 & 0.975 & 0.979 \\
\hline & 2 & 0.958 & & \\
\hline & 3 & 0.957 & & \\
\hline & 4 & 0.924 & & \\
\hline & 5 & 0.929 & & \\
\hline & 6 & 0.937 & & \\
\hline \multirow[t]{5}{*}{ Competitiveness } & 1 & 0.918 & 0.981 & 0.966 \\
\hline & 3 & 0.864 & & \\
\hline & 4 & 0.945 & & \\
\hline & 5 & 0.951 & & \\
\hline & 6 & 0.933 & & \\
\hline
\end{tabular}


To validate the measurement model, the coefficient of convergent and discriminant validity is calculated. Convergent validity assesses the extent to which a measure is highly correlated with alternative measures measuring the same construct (Hair et al., 2014). Discriminant validity ensures that construct measures are empirically unique and represent phenomena of interest that are not captured by other measures in the structural equation model. In this study, all constructs are modeled as reflective constructs so that all indicators must have a high proportion of variance (Hair et al., 2014). To find out the convergent validity, the indicator reliability coefficient (factor loadings), Average Variance Extracted (AVE) and Composite Reliability (CR) were calculated, the results of which can be seen in table 1. The Factor Loading value of most of the statement items is above the threshold value, which is 0.4 (Hair et al., 2014). However, there are 5 items excluded from the model because they have a loading factor below 0.4, namely the Government Support variable statement items number 24, 25 and 26 , then the Digital Capability variable statement item number 6, and the competitiveness variable statement item number 2. AVE value for all variables are above 0.5 thus confirming the convergent validity (Hair et al., 2010; Henseler et al., 2009).

Next, the Composite Reliability (CR) coefficient is examined to assess the reliability of the measurement, as it prioritizes indicators based on individual reliability. Based on the calculation results, all CR values are greater than 0.7 which indicates that the measurement is reliable. Hair et al. (2014) stated that Cronbach's alpha estimates reliability based on the correlation between variable indicators while CR is based on individual indicators. Discriminant validity was assessed by comparing the square root of the AVE value with the latent variable correlation (Hair et al., 2014; Fornell and Larcker, 1981). As shown in Table 2, the square root of AVE for each construct is higher than the correlation for the other constructs in this study, which confirms the discriminant validity of the construct.

Table 2. Discriminant Validity

\begin{tabular}{lcccc}
\hline \multicolumn{1}{c}{ Variable } & $\mathbf{1}$ & $\mathbf{2}$ & $\mathbf{3}$ & $\mathbf{4}$ \\
\hline Digital Capabilities & 0.923 & - & - & - \\
Government Support & 0.693 & 0.888 & - & - \\
Digital innovation & 0.699 & 0.694 & 0.942 & - \\
Competitiveness & 0.827 & 0.679 & 0.750 & 0.877 \\
\hline
\end{tabular}

\section{b. Analysis of Stuctural Model (Inner Model)}

Table 3. Hypotheses Testing

\begin{tabular}{clcccc}
\hline Hypotheses & \multicolumn{1}{c}{ Direct affect } & Path Coefficient & T Statistics & P Values & Note \\
\hline $\mathbf{H 1}$ & $\begin{array}{l}\text { GovernmentSupport } \longrightarrow \\
\text { Digital Capability }\end{array}$ & 0.679 & 9.934 & 0.000 & Accept \\
\hline $\mathbf{H 2}$ & $\begin{array}{l}\text { GovernmentSupport } \longrightarrow \\
\text { Digital Innovation }\end{array}$ & 0.341 & 2.383 & 0.017 & Accept \\
\hline $\mathbf{H 3}$ & $\begin{array}{l}\text { GovernmentSupport } \longrightarrow \\
\text { Competitiveness }\end{array}$ & 0.401 & 4.332 & 0.000 & Accept \\
\hline $\mathbf{H 4}$ & $\begin{array}{l}\text { Digital Capability } \longrightarrow \\
\text { Digital Innovation }\end{array}$ & 0.519 & 3.861 & 0.000 & Accept \\
\hline $\mathbf{H 5}$ & $\begin{array}{l}\text { Digital Innovation } \\
\text { Competitiveness }\end{array}$ & 0.421 & 4.546 & 0.000 & Accept \\
\hline
\end{tabular}

In terms of hypothesis testing, an analysis of the structural model is carried out to evaluate the relationship between variables. As shown in Table 3 and Figure 4, the direct effect of Government Support on Digital Innovation is positive and significant $(b=0.341$ and $p<0.05)$, the direct effect of Government Support on Digital Capability is positive and significant $(b=0.679$ and $p<0.01)$. ), the direct influence of Government Support on Competitiveness is positive and significant $(b=0.401$ and $p<0.01)$, the direct effect of Digital Innovation on Competitiveness is positive and significant $(b=0.421$ and $\mathrm{p}<0.01)$, and the direct effect of Digital Capability on Digital innovation was also positive and significant $(b=0.519$ and $p<0.01)$. Therefore, Hypothesis 1 , Hypothesis 2, Hypothesis 3, Hypothesis 4 and Hypothesis 5, can be accepted. The value of R2 (r square) in the endogenous variables of Digital Capability, Digital Innovation, and Competitiveness, respectively, is $0.461,0.626$ and 0.572 , as shown in Figure 4. It means that the variance in each endogenous variable can be explained by the 
exogenous variable of $46.1 \%, 62.6 \%$ and $57.2 \%$. Government support (DUKP) is an exogenous variable, so there is no R square value for that variable. While the magnitude of the influence of Government Support on Digital Capability, Digital Innovation and Competitiveness are 0.679, 0.341 and 0.401 .

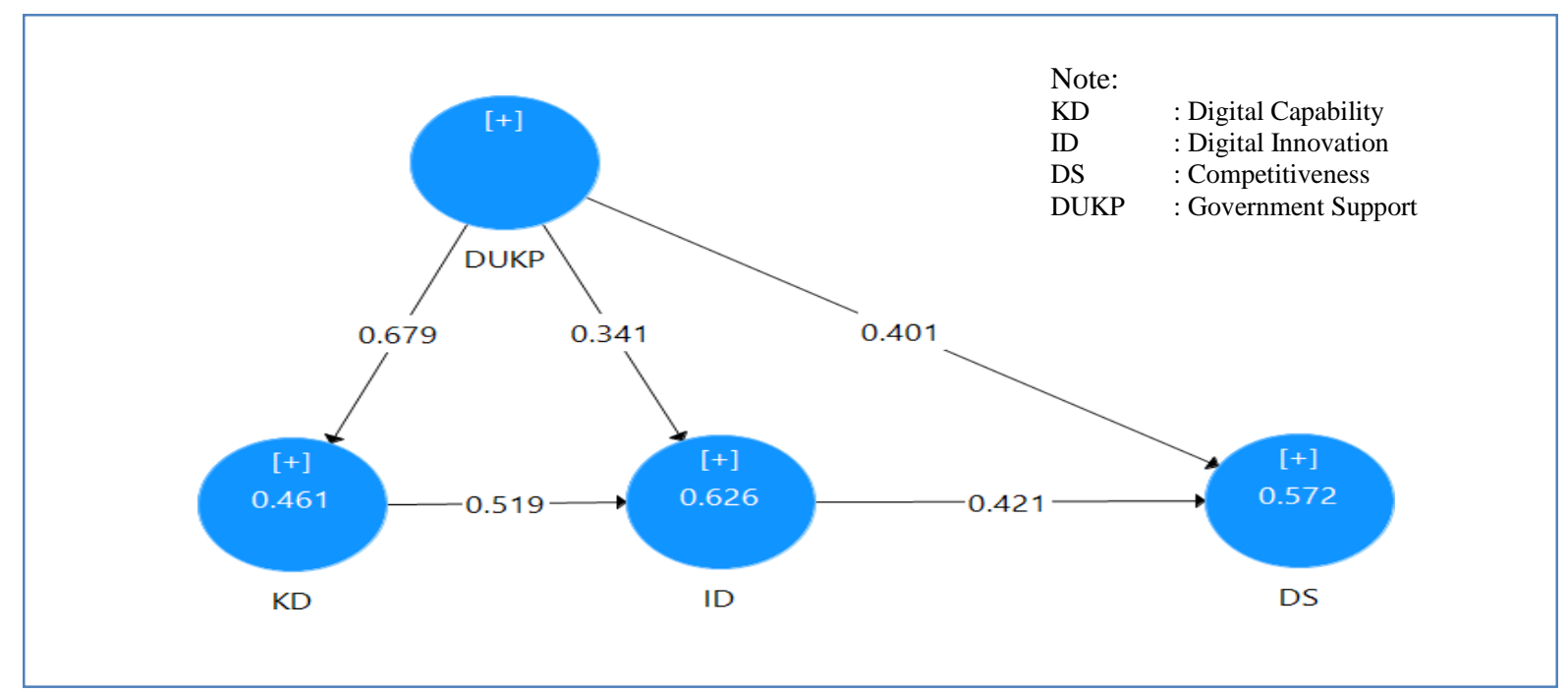

Figure 4. PLS-SEM Output

From the results of hypothesis testing, it can be seen that $\mathrm{H} 1, \mathrm{H} 2, \mathrm{H} 3, \mathrm{H} 4$, and $\mathrm{H} 5$ are accepted. For government support variables affect digital capabilities, digital innovation and competitiveness. This shows that the government is required to provide adequate technical, manufacturing, consulting, financial, information, learning, human resource development and export support to increase the capability, innovation and competitiveness of cooperatives. With regard to technical and manufacturing support, the government needs to provide business funding and business development that can be provided through the cooperative innovation incentive program. The creation of networks and technology platforms for cooperatives is also needed as a form of consultancy support. The government also needs to simplify the loan system for cooperatives that focus on using or utilizing appropriate technology. The support from the learning and human resource development side of the government is still lacking by cooperatives in the city of Bandung. Cooperatives really need guidance and government programs to help increase digital competence in cooperative management so that they can compete both nationally and internationally. In the international sphere, the government needs to facilitate and initiate the formation of cooperative cooperation with organizations abroad, including in introducing cooperative products to the international world through the use of digital media.

Digital capabilities also affect the level of digital innovation for cooperatives in Bandung. Digital capabilities include Dynamic Managerial Capabilities and Organizational Capabilities. Dynamic Managerial Capabilities consist of Managerial Cognition, Managerial Social Capital and Managerial Human Capital. There is room for improvement for cooperatives to increase the level of digital innovation by focusing on managerial cognition. Capacity building related to the understanding of cooperative employees regarding environmental situations, markets, business development trends in the future is needed. In addition, employees need to be trained to be more responsive to change. The ability to respond to a wide range of environments and adapt quickly is very important. The next hypothesis shows that digital innovation has an effect on the competitiveness of cooperatives both nationally and internationally. Cooperatives still need support in developing current products into digital products. When the product is developed it also needs to be followed by determining the momentum to market the product to the market. It must be kept up to date with the digital products produced by the cooperative when they are launched so that they have a higher value than other products.

With responsive actions to eliminate gaps that arise both in terms of digital capabilities, digital innovation and government support, it is hoped that the competitiveness of cooperatives will increase both nationally and internationally. It should be noted that the role of the government at this time is very much needed to provide financial and non-financial support. With a large number of cooperatives in Bandung City, the government must be more selective in determining aid priorities. Cooperatives also need to develop cooperation with other parties besides the government, such as other industries, academics, media and the community to jointly develop 
cooperatives that have a positive impact on the better life of Indonesian people. The consistency and commitment of cooperatives to continue learning and improving themselves will have implications for profitability, efficiency and growth. In this case the cooperative will have a low level of risk due to the possibility of financial difficulties, optimal utilization of physical and non-physical resources and in the long term there will be an increase in cooperative assets. Figure 5 describe the development model of competitiveness for cooperatives in Bandung through digital capability, digital innovation and government support

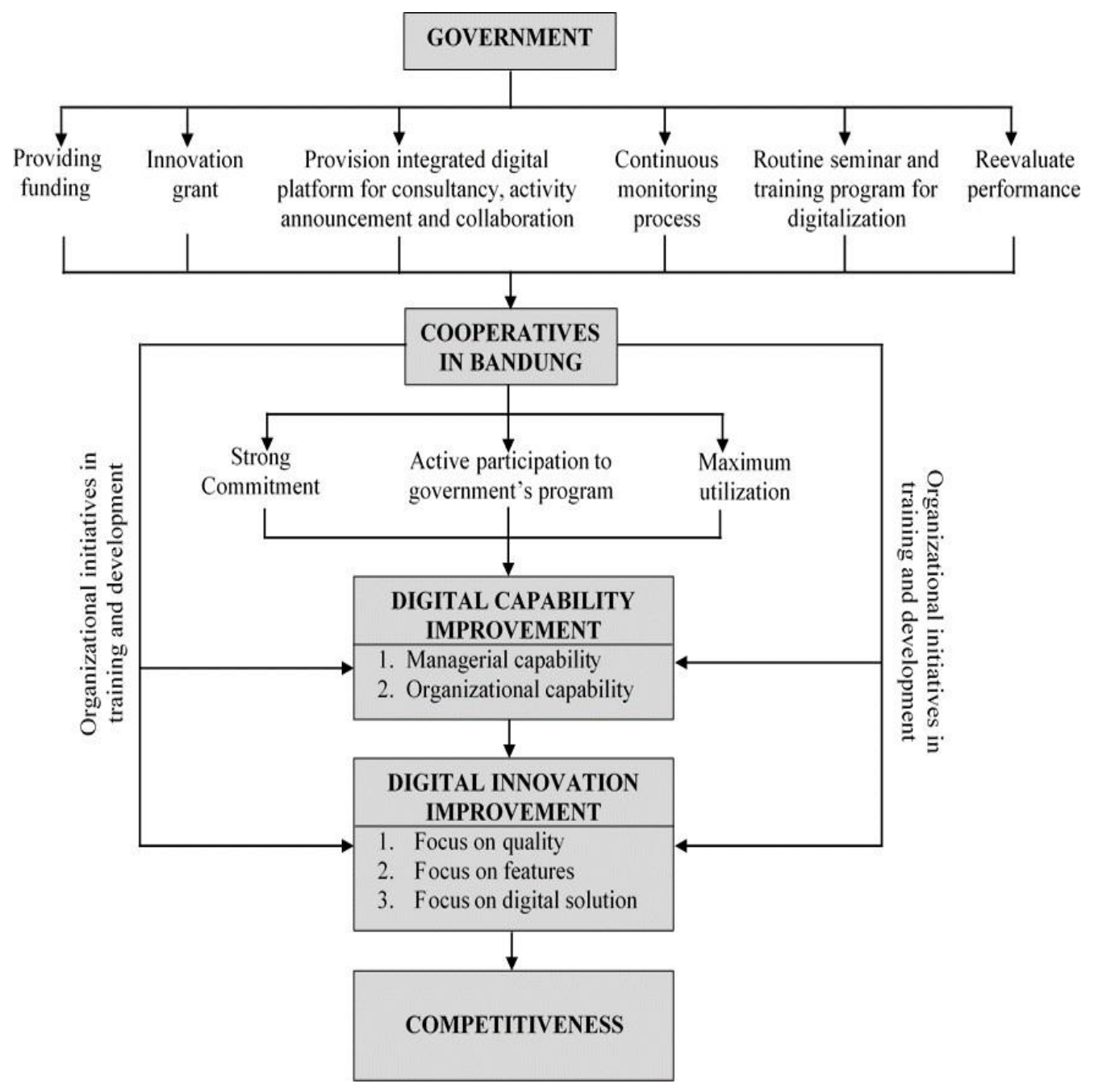

Figure 5. The Development Model of Competitiveness for Cooperatives

\section{CONCLUSIONS}

Based on the results of hypothesis testing, it is concluded that government support has a significant impact on digital capabilities, digital innovation and the competitiveness of cooperatives in the city of Bandung. Then digital capabilities affect competitiveness with digital innovation as an intervening variable. In this case, the cooperative and the government have a role to collaborate with each other to increase competitiveness in the current digital era. The things that can be done by each party are as follows:

1. Government Roles

a) Government of Bandung City needs to focus on providing business funding in order to fulfill the facilities and infrastructure that support the development of cooperatives. The government can create an innovation grant program that focuses on the match between the proposed funding and the output to be achieved. A 
continuous monitoring process is needed, including assistance to overcome the obstacles that arise until the expected output is achieved.

b) Provision of a digital platform that can become a forum for cooperatives in Bandung to be able to interact, display profiles and products owned by each cooperative. There are consultants who are responsible for discussing problems raised by cooperatives through this digital platform. This platform can also be used as an information medium for government activities or programs that cooperatives can participate in, including opportunities for cooperation with domestic and foreign agencies. The government can also monitor the activeness of cooperatives in using the platforms provided and provide rewards for the most active cooperatives.

c) Prioritizing loan disbursements with an easier process related to the use of appropriate technology that can boost cooperative competitiveness.

d) Adding a cooperative performance appraisal indicator that will determine the status or grade of the cooperative, especially for grade A with assessment points related to the digital innovations produced.

e) Carry out routine training programs both general and specific for cooperatives grouped by type of cooperation to make them relevant to their business scope. The training program should be made in the form of a roadmap to see the increase in value and its impact on the digital capabilities of the cooperative.

f) Creating a seminar program that focuses on increasing knowledge of cooperatives regarding the latest environmental developments, the trend of behavior and lifestyle of people in the digital era, as well as people's preferences for a product and its benefits.

2. Cooperatives Roles

a) Consistently and actively participate in programs that have been made by the government

b) Actively discussing and maximizing the digital platform provided as a medium for introducing cooperative products, collaborating and other labor.

c) Utilize and implement the expertise gained from training activities and seminars organized by the government to improve employee digital capabilities.

\section{ACKNOWLEDGEMENT}

The research presented in this paper was conducted by the School of Economics and Business, Telkom University and funded by a research grant from Indonesian Ministry of Education, Culture, Research and Technology. We also would like to express our gratitude to Directorate of Research and Public Services, Telkom University for having contributed to the success of this study.

\section{REFERENCES}

Adner, R., \& Helfat, C. E. (2003). Corporate effects and dynamic managerial capabilities. Strategic Management Journal, 24(10), 1011-1025. https://doi.org/10.1002/smj.331

Anderson, J.C. and Gerbing, D.W. (1988), "Structural equation modeling in practice: a review and recommended two-step approach", Psychological Bulletin, Vol. 103 No. 3, pp. 411-423

Anwar, M., \& Li, S. (2020). Spurring competitiveness, financial and environmental performance of SMEs through government financial and non-financial support. Environment, Development and Sustainability. https://doi.org/10.1007/s10668-020-00951-3

Asunka, B. A. (2016). The Significance of Information and Communication Technology for SMEs in Rural Communities. Journal of Small Business and Entrepreneurship Development, 4(2). https://doi.org/10.15640/jsbed.v4n2a4

Dobes, K., Kot, S., Kramolis, J., \& Sopkova, G. (2017). The Perception of Governmental Support in The Context of Competitiveness of SMEs in the Czech Republic. Journal of Competitiveness, 9(3), 34-50. https://doi.org/10.7441/joc.2017.03.03

Fornell, C. \& Larcker, D.F. (1981), "Evaluating structural equation models with unobservable variables and measurement error", Journal of Marketing Research, Vol. 18 No. 1, pp. 39-51.

Ghozali, I., \& Latan, H. 2014. Partial Least Squares Konsep, Metode dan Aplikasi Menggunakan Program 
WARPPLS 4.0. Badan Penerbit Universitas Diponegoro. ISBN : 978.602.097.229.9

Garud, R., Tuertscher, P., \& Van de Ven, A. H. (2013). Perspectives on Innovation Processes. The Academy of Management Annals, 7(1): 775-819. https://doi.org/10.1080/19416520.2013.791066

Hair, J.F., Hult, G.T., Ringle, C.M. \& Sarstedt, M. (2014), A Primer on Partial Least Squares Structural Equation Modeling (PLS-SEM), Thousand Oaks : Sage Publication

Hana, U. (2013). Competitive Advantage Achievement through Innovation and Knowledge. Journal of Competitiveness, 5(1), 82-96. https://doi.org/10.7441/joc.2013.01.06

Hartono, H., \& Halim, E. (2020). The Effect of Digital Capability on Competitiveness through Digital Innovation of E-Travel Business in Indonesia. 2020 International Conference on Information Management and Technology (ICIMTech), 615-620. https://doi.org/10.1109/ICIMTech50083.2020.9211228

Helfat, C. E., \& Martin, J. A. (2015). Dynamic Managerial Capabilities: Review and Assessment of Managerial Impact on Strategic Change. Journal of Management, 41(5), 1281-1312. https://doi.org/10.1177/0149206314561301

Helfat, C. E., \& Winter, S. G. (2011). Untangling Dynamic and Operational Capabilities: Strategy for the (N)everChanging World. Strategic Management Journal, 32(11), 1243-1250. https://doi.org/10.1002/smj.955

Henfridsson, O., Mathiassen, L., \& Svahn, F. (2014), "Managing technological change in the digital age: the role of architectural frames", Journal of Information Technology, Vol. 29 No. 1, pp. 27-43.

Hoffman, D. 2018. Shaping Wellsprings of Innovation: towards Organizational design configurations for digital innovation management. Proceeding at Twenty-Six European Conference on Information Systems (ECIS 2018). Portsmouth : UK

Khan, K. U., Atlas, F., Ghani, U., Akhtar, S., \& Khan, F. (2020). Impact of intangible resources (dominant logic) on SMEs innovation performance, the mediating role of dynamic managerial capabilities: Evidence from China. European Journal of Innovation Management, ahead-of- print(ahead-of-print). https://doi.org/10.1108/EJIM-07-2020-0276

Khin, S., \& Ho, T. C. (2019). Digital technology, digital capability and organizational performance: A mediating role of digital innovation. International Journal of Innovation Science, 11(2), 177-195. https://doi.org/10.1108/IJIS-08-2018-0083

Kim, M., \& Lee, S. Y. (2011). The effects of government financial support on business innovation in South Korea. Asian Journal of Technology Innovation, 19(1), 67-83. https://doi.org/10.1080/19761597.2011.578426

Kolisnichenko, P. (2017). Government support for small and medium-sized business and innovative activities. Baltic Journal of Economic Studies, 3(4), 115-119. https://doi.org/10.30525/2256-0742/2017-3-4-115-119

Li, L., Su, F., Zhang, W., \& Mao, J.-Y. (2018). Digital transformation by SME entrepreneurs: A capability perspective. Information Systems Journal, 28(6), 1129-1157. https://doi.org/10.1111/isj.12153

M.tribunnews.com. 26 July 2019. "775 Koperasi di Kabupaten Bandung Mati Suri, Ini Penyebabnya". Accessed on August 2019. https://www.tribunnews.com/regional/2019/07/26/775- koperasi-di-kabupaten-bandung mati-suri-ini-penyebabnya

Nambisan, S., Majchrzak, A., \& Song, M. (2017). Digital Innovation Management: Reinventing Innovation Management Research in a Digital World. MIS Quarterly, 41(1), 223-238. https://doi.org/10.25300/MISQ/2017/41:1.03

Nelson, R. (1992). Recent Writings on Competitiveness: Boxing the Compass. California Management Review, 34(2), 127-137. https://doi.org/10.2307/41166697

Paladino, A. (2007). Investigating the Drivers of Innovation and New Product Success: A Comparison of Strategic Orientations. Journal of Product Innovation Management, 24(6), 534- 553. https://doi.org/10.1111/j.1540$\underline{5885.2007 .00270 . x}$

Ringle, C.M., Wende, S., \& Will, A. (2005), SmartPLS, Hamburg, available at: www.smartpls.de

Urbach, N., \& Ahlemann, F. (2010), "Structural equation modeling in information systems research using partial least squares", Journal of Information Technology Theory and Application, Vol. 11 No. 2, pp. 5-40

Waheeduzzaman, A. N. M., \& Ryans, J. K. (1996). Definition, perspectives, and understanding of international competitiveness: a quest for a common ground. Competitiveness Review, 6(2), 7-26. 
https://doi.org/10.1108/eb046333

Wei, J., \& Liu, Y. (2015). Government support and firm innovation performance: Empirical analysis of 343 innovative enterprises in China. Chinese Management Studies, 9(1), 38-55. https://doi.org/10.1108/CMS$\underline{01-2015-0018}$

Wisenthige, K., \& Guoping, C. (2016). Firm Level Competitiveness of Small and Medium Enterprises (SMEs): Analytical Framework Based on Pillars of Competitiveness Model. International Research Journal of Management, IT \& Social Sciences, 3(9s), 51. https://doi.org/10.21744/irjmis.v3i9.172 